\title{
Distinct Modes of Neuronal Migration in Different Domains of Developing Cerebellar Cortex
}

\author{
Hitoshi Komuro and Pasko Rakic \\ Section of Neurobiology, Yale University School of Medicine, New Haven, Connecticut 06510
}

As postmitotic neurons migrate to their final destinations, they encounter different cellular microenvironments, but functional responses of migrating neurons to changes in local environmental cues have not been examined. In the present study, we used a confocal microscope on acute cerebellar slice preparations to examine real-time changes in the shape of granule cells, as well as the mode and rate of their migration as they transit different microenvironments. The rate of granule cell movement is fastest in the molecular layer, whereas their elongated somata and long leading processes remain in close contact with Bergmann glial fibers. Cell movement is slowest in the Purkinje cell layer after granule cells detach from the surface of Bergmann glia and the somata become transiently round, whereas the leading processes considerably shorten. Surprisingly, after entering the internal granular layer, granule cells re-extend both their somata and leading processes as they resume rapid movement independent of Bergmann glial fibers. In this last phase of migration, described here for the first time, most granule cells move radially for $>100 \mu \mathrm{m}$ (a distance comparable to that observed in the molecular layer) until they reach the deep strata of the internal granular layer, where they become rounded again and form synaptic contacts with mossy fiber terminals. These observations reveal that migrating neurons alter their shape, rate, and mode of movement in response to local environmental cues and open the possibility for testing the role of signaling molecules in cerebellar neurogenesis.

Key words: cerebellar development; neuronal cell migration; confocal microscopy; brain slice preparation; fluorescent carbocyanine dye; rate of cell movement
Since the initial description by Ramon y Cajal (1911), the morphogenetic transformation of migrating granule cells has been studied mostly in static preparations of fixed tissue of the postnatal cerebellum (Uzman, 1960; Miale and Sidman, 1961; Fujita, 1967; Mugnaini and Forstronen, 1967; Altman, 1972). These studies using $\left[{ }^{3} \mathrm{H}\right]$ thymidine labeling, electron microscopy, and immunocytochemistry have suggested that, after their final mitotic division, granule cells actively move through the developing molecular layer (ML) to the Purkinje cell layer (PCL). Furthermore, combined use of electron microscopy and Golgi impregnation methods has indicated that granule cell migration is guided by surface-mediated interactions with Bergmann glial fibers that traverse the developing molecular layer (Rakic, 1971, 1981, 1985). Moreover, the use of dissociated cell culture added experimental evidence to these interpretations (Trenkner and Sidman, 1977; Edmondson and Hatten, 1987; Hatten and Mason, 1990). However, these studies have been confined to the description of cell migration across the ML, whereas little is known about granule cell translocation across the PCL and the extent of granule cell movement within the internal granular layer (IGL). Because granule cells lose contact with the surface of Bergmann glial fibers after leaving the ML, it remains unclear whether the further movement of these cells is attributable to a passive displace-

Received Sept. 5, 1997; revised Nov. 24, 1997; accepted Nov. 26, 1997.

This research was supported by the United States Public Health Service. We gratefully acknowledge Dr. C. Takayama for discussions during the course of this work. We also thank Drs. E. Anton, D. Kornack, D. Stull, and K. Wikler for their useful suggestions and comments on this manuscript.

Correspondence should be addressed to Dr. Hitoshi Komuro, Section of Neurobiology, Yale University School of Medicine, 333 Cedar Street, New Haven, CT 06510

Copyright (C) 1998 Society for Neuroscience $\quad 0270-6474 / 98 / 181478-13 \$ 05.00 / 0$ ment or an active process reminiscent of their earlier glial cellassociated migration.

Determining how granule cells migrate through these three major microenvironmental compartments of the developing cerebellum is critical, because cell adhesion and extracellular matrix molecules exhibit distinct spatial expression sequences in the ML, PCL, and IGL (Choung et al., 1987; Choung, 1990; Cameron et al., 1997). In addition, granule cells express different complements of genes along their migratory pathway, including genes that encode for specific receptors activated by cell adhesion molecules (Kuhar et al., 1993; Rocamora et al., 1993; Hatten and Heintz, 1995; Zheng et al., 1996; Hatten et al., 1997). These dynamic position-specific changes in granule cell gene expression raise the possibility that the cells may alter their shape and mode of migration in response to local environmental cues as they traverse different cortical layers.

The recent development of acute slice preparations allows the direct observation of granule cell movement within the natural cellular milieu (Komuro and Rakic, 1992, 1993, 1995, 1997). We can now determine how an identified granule cell changes its shape and migratory behavior as it encounters different cellular components in the developing cerebellum. The present results indicate that, after entering the PCL and IGL, granule cells may change the mode of migration and may use different extrinsic and intrinsic signals than those used during translocation across the ML.

\section{MATERIALS AND METHODS}

Cerebellar slice preparations. Postnatal 10-d-old mice (CD-1) were killed by decapitation, in accordance with institutional guidelines. Cerebella were quickly removed from the skull and placed in cold $\left(5^{\circ} \mathrm{C}\right) \mathrm{HBSS}(40$ $\mathrm{mm}$ glucose). Before cutting, cerebella were embedded in $20 \%$ gelatin and sectioned sagittally into $300-400 \mu \mathrm{m}$ slices on a Vibro Slice microtome (Stoelting). After sectioning, pia mater and gelatin were carefully 


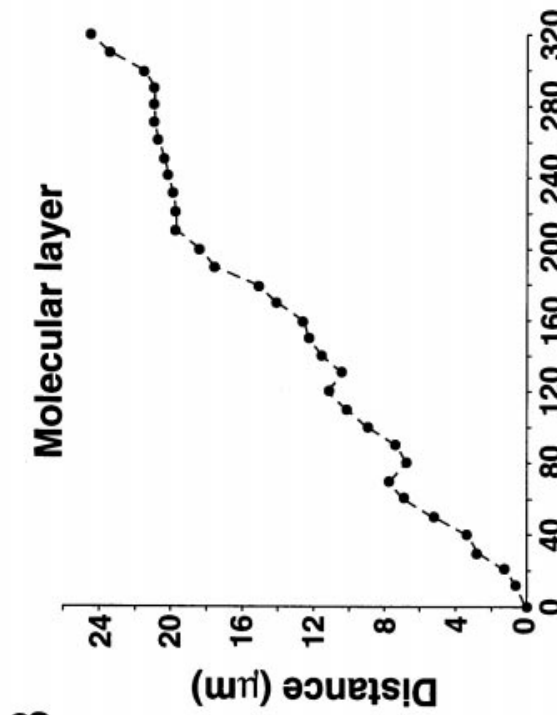

$\mathbf{m}$
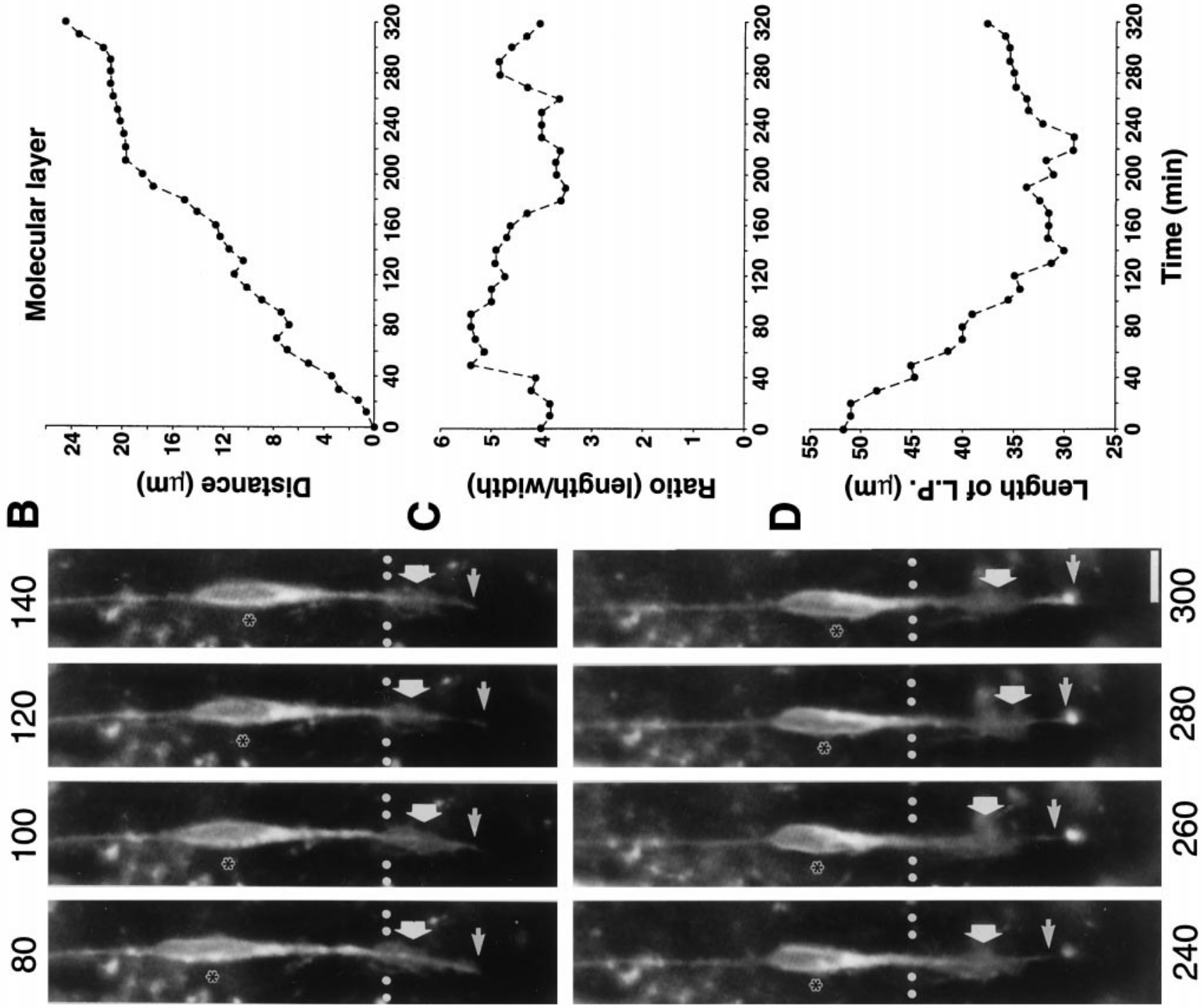

\section{온}
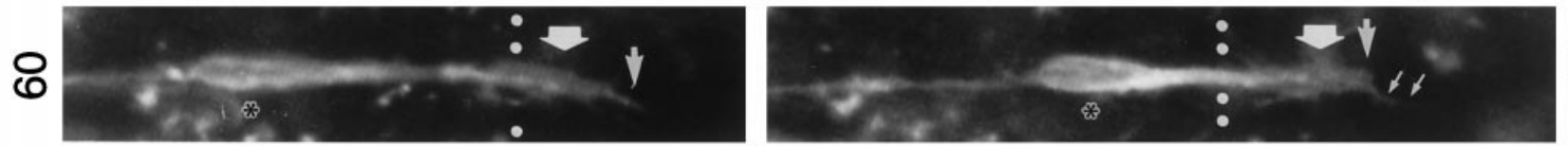

\section{సิ}
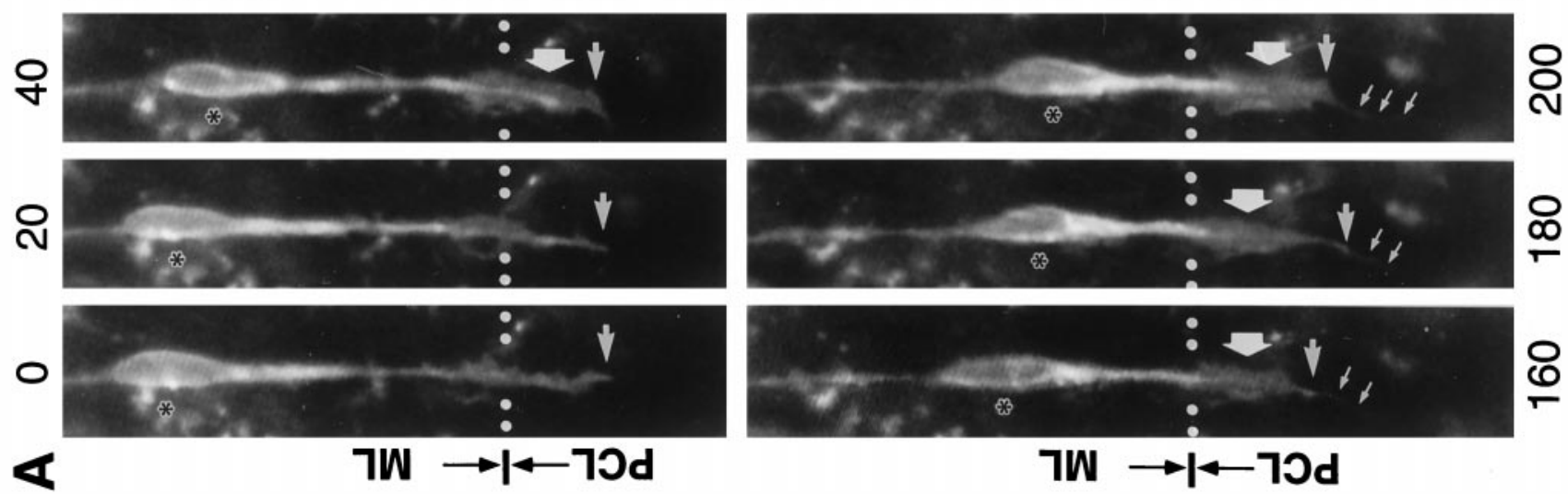

Figure 1. Time-lapse series of images illustrating transformation of granule cell leading process during its penetration of the PCL. A, Example of a granule cell labeled with DiI near the ML-PCL border. During the observation period, the spindle-shaped soma (asterisks) gradually moved from the ML toward the ML-PCL border. Wide arrows and small arrows indicate motile lamellipodia and filopodia, respectively. The distance traversed by the granule cell soma $(B)$, the length/width ratio of the soma $(C)$, and the leading process length $(D)$ were plotted as a function of elapsed time. $P C L$, Purkinje cell layer; $M L$, molecular layer. Scale bar, $10 \mu \mathrm{m}$. Time interval (in minutes) is indicated on either the top or bottom. 

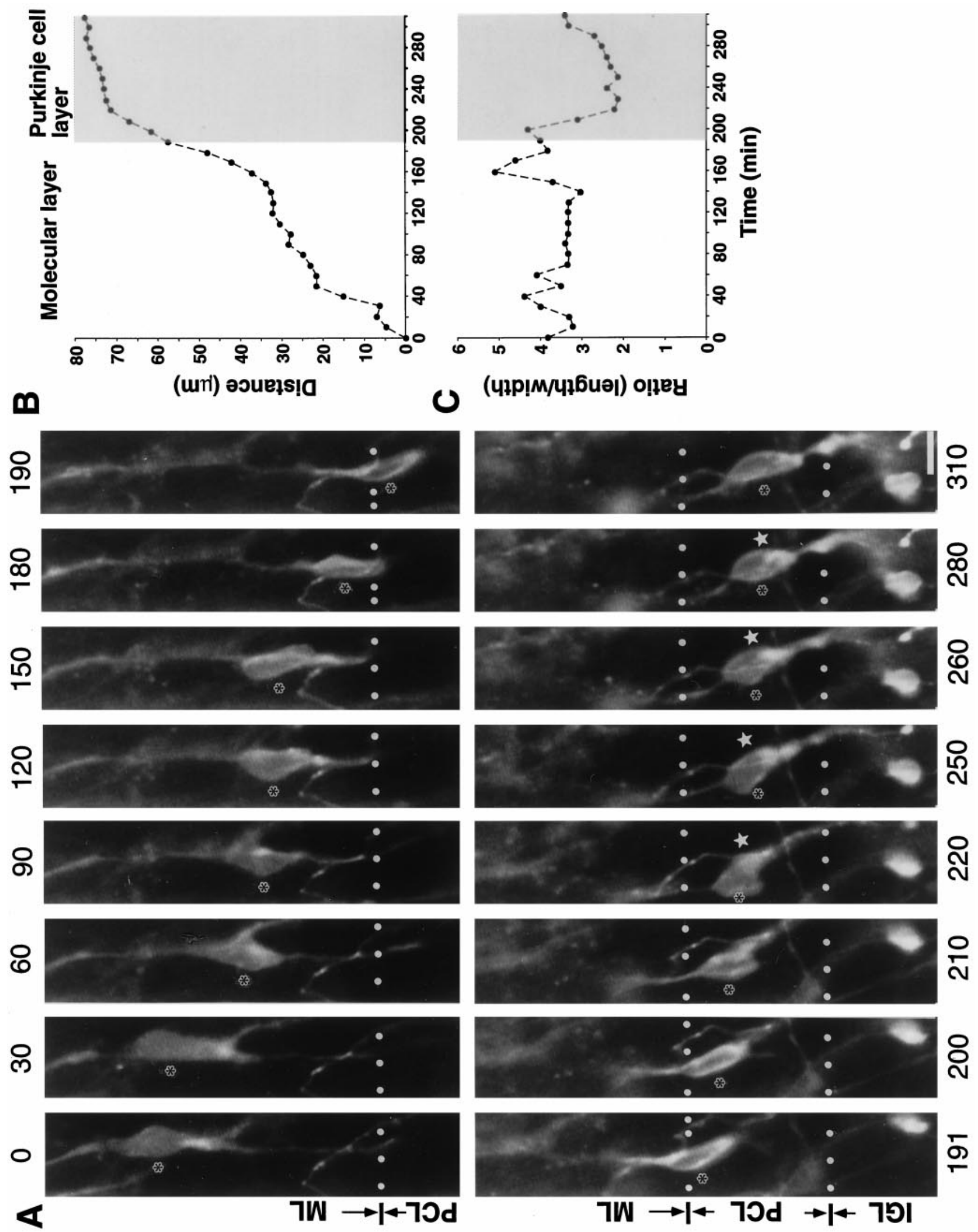

Figure 2. Time-lapse series showing an example a granule cell in the PCL. A, After granule cells crossed the ML-PCL border, they became rounded (white stars). Each asterisk indicates the soma of a granule cell. The distance traversed by the granule cell soma $(B)$ and the length/width ratio of the soma $(C)$ were plotted as a function of elapsed time. $I G L$, Internal granular layer; $P C L$, Purkinje cell layer; $M L$, molecular layer. Scale bar, $10 \mu \mathrm{m}$. Time interval (in minutes) is indicated on either the top or bottom. 
removed under a dissecting microscope. The use of sagittal slices obtained from the middle region of the cerebellum allowed us to observe granule cell movement in a single focal plane from their origin in the external granular layer (EGL) to their final position in the IGL. However, because parallel fibers of migrating granule cells may be bisected during the sectioning of slices in this plane, we also examined the rate of granule cell movement in 300-400 $\mu \mathrm{m}$ sections sliced coronally, to minimize damage to growing parallel fibers. The results did not reveal a significant difference in the shape of migrating granule cells or the mode and rate of their migration between sagittal and coronal slices $(\mathrm{H}$. Komuro and P. Rakic, unpublished observations). Therefore, only the results from the observation on sagittal slices were used for the data presented in the present study.

DiI Labeling. To label migrating granule cells, cerebellar slices were incubated for $3 \mathrm{~min}$ at $20^{\circ} \mathrm{C}$ in a fluorescent lipophilic carbocyanine dye, $1,1^{\prime}$-dioctadecyl-3,3,3',3'-tetramethylindocarbocyanine perchlorate (DiI, $7.2 \mu \mathrm{g} / \mathrm{ml}$; Molecular Probes, Eugene, OR) added to the cell culture medium (Honig and Hume, 1986). The incubation medium consisted of minimum essential medium (MEM; Life Technologies, Gaithersburg, MD) supplemented with $40 \mathrm{~mm}$ glucose, $1.8 \mathrm{~mm}$ glutamine, $24 \mathrm{~mm}$ $\mathrm{NaHCO}_{3}$, penicillin $(90 \mathrm{U} / \mathrm{ml})$, and streptomycin $(90 \mu \mathrm{g} / \mathrm{ml})$. After rinsing in the incubation medium, brain slices were maintained in an incubator $\left(37^{\circ} \mathrm{C}, 95 \% \mathrm{O}_{2}, 5 \% \mathrm{CO}_{2}\right)$ for an additional 2-4 hr. Brain slices were then transferred into the chamber of a microincubator (PDMI-2, Medical System) attached to the stage of an inverted microscope (IMT-2; Olympus Optical, Tokyo, Japan). The rate of cell movement is related closely to the temperature of the medium; lowering the medium temperature slows cell movement (Rakic and Komuro, 1995). Therefore, chamber temperature was kept at $37.0 \pm 0.5^{\circ} \mathrm{C}$ using a temperature controller (TC-202, Medical System), and the slices were provided with constant gas flow $\left(95 \% \mathrm{O}_{2}, 5 \% \mathrm{CO}_{2}\right)$. To prevent movement of the slice preparation during observation, a nylon net glued to a small silver wire ring was placed over the preparations.

Observation of granule cell migration. A laser scanning confocal microscope (MCR-600; Bio-Rad, Hercules, CA) was used to visualize migrating granule cells labeled with DiI in the slices (Komuro and Rakic, 1995; Rakic and Komuro, 1995). The use of this microscope permitted highresolution imaging of migrating neurons up to $120 \mu \mathrm{m}$ deep within the tissue slices. The tissue was illuminated with $514 \mathrm{~nm}$ wavelength light from an argon laser through an epifluorescence inverted microscope equipped with a $40 \times$ water immersion objective (Zeiss; numerical aperture, 0.75). Light passing through the aperture was filtered by a $550 \mathrm{~nm}$ long-pass filter. To resolve movement of migrating cells clearly, image data typically were collected at an additional electronic zoom factor of 2-3. Time-lapse imaging of live, fluorescently labeled cells can produce phototoxic effects in the imaged cells. Indeed, when well stained cells were imaged with very high incident illumination intensity or imaged too frequently, we invariably saw changes in the structure or dynamics of migrating granule cells. However, when the incident illumination was sufficiently attenuated, labeled specimens could be imaged (10 min intervals) for many hours without signs of photodynamic damage. To protect the migrating granule cells labeled with DiI from any cytotoxic effect of the laser beam, neutral density filters were added to reduce the excitation light level by $99 \%$. To avoid injured granule cells located near the sectioning surfaces, we examined the shape and behavior of migrating granule cells located $15-120 \mu \mathrm{m}$ below the surface of the slices. If granule cells showed no evidence of motility for $>300 \mathrm{~min}$, the brain slice was discarded. Shock to the tissue during sectioning of slices can disrupt cell movement and can prevent cells from migrating. Accordingly, the present study is based on the analysis of approximately one-third of the healthy slices, which had displayed cell migration. This sampling procedure favored slices in which cells displayed visible and robust movement shortly after sectioning. Images of the migrating granule cells in a single focal plane were collected with laser scans every $10 \mathrm{~min}$ for up to $10 \mathrm{hr}$ and recorded on an optical disk recorder (TQ-3031, Panasonic) or an optical drive (cosmos 600, Racet). At the beginning and end of each recording session for each preparation, frame images were recorded with $40 \times$ magnification (electronic zoom factor of 1 ) or $20 \times$ magnification (electronic zoom factor of 1) to determine the orientation of slice preparations, the borders between cerebellar cortical layers, and the position of granule cells within cortical layers by optical sectioning of several different focal planes along the $z$ axis. Statistical significance between experimental groups was tested by Student's $t$ test.

The length/width ratio of the soma and leading process length of each migrating granule cell were determined manually with a mouse-driven imaging software package. The leading process length was defined as the linear distance between its tip and its base. The distance traveled by a migrating granule cell was defined as the absolute value of the changes in its position during the entire time-lapse session.

\section{RESULTS}

\section{Transformation of granule cells during and after penetration of the PCL}

First, we examined the changes in the shape and behavior of DiI-labeled granule cells in the deep strata of the ML as they approach the PCL. The cell illustrated in Figure $1 A$ was visualized $3 \mathrm{hr}$ after staining and recorded in optical sections at $10 \mathrm{~min}$ intervals for up to $320 \mathrm{~min}$. At the beginning of recording, it had a vertically elongated cell body, a thin trailing process, and a voluminous leading process, such as described in Golgi impregnation material (Ramon y Cajal, 1911; Rakic, 1971). During the observation period, the granule cell soma, initially located $\sim 40$ $\mu \mathrm{m}$ away from the ML-PCL border, gradually moved toward the PCL with an elongated bipolar shape (length/width ratio, 3.8-5.3; Fig. $1 B, C)$. However, the tip of the leading process, which had penetrated the PCL, did not extend, and, as a result, its length decreased from 52 to $30 \mu \mathrm{m}$ (Fig. $1 D$ ). The shortening of the leading process was caused by the advance of the granule cell soma within the leading process rather than active retraction. The distal portion of the leading process positioned in the PCL had large motile lamellipodia and filopodia (Fig. $1 \mathrm{~A}$, wide arrows and small arrows, respectively). This is uncharacteristic of the leading process of migrating granule cells in the ML, which is associated with Bergmann glial fibers, and usually tapers without motile lamellipodia (Rakic, 1985; Komuro and Rakic, 1992). The present results demonstrate that the granule cell leading process undergoes a dynamic transformation after penetrating the upper strata of the PCL, whereas the soma does not exhibit distinct changes in form and rate of movement as it transits the ML. Because Bergmann glial cell somata are located at the upper strata of the PCL (Mugnaini and Forstronen, 1967; Rakic, 1971), these dynamic changes in the shape and movement of the granule cell leading process are the initial signs that the tip of the leading process has detached from the surface of Bergmann glial cells in the upper strata of the PCL.

Next, we examined changes in granule cell shape and the rate of movement during the final stage of Bergmann glia-guided migration in the upper strata of the PCL. The soma of a granule cell (Fig. $2 A$ ) that was located initially in the deep strata of the ML (46 $\mu \mathrm{m}$ away from the ML-PCL border) gradually moved toward the PCL before crossing the ML-PCL border $3 \mathrm{hr}$ after the start of recording. The movement of the soma slowed significantly during this period, from $18.0 \mu \mathrm{m} / \mathrm{hr}$ in the ML to 9.5 $\mu \mathrm{m} / \mathrm{hr}$ in the PCL (Fig. $2 B$ ). After the soma became round (Fig. $2 C$ ), the rate of movement decreased further to $\sim 4.0 \mu \mathrm{m} / \mathrm{hr}$.

Figure 3, $A$ and $C$, shows that, once the granule cell entered the PCL, the shape of its soma transformed from a vertically elongated spindle (a length/width ratio of 3.0-4.5) to a sphere (a length/width ratio of 1.3-2.8). The rate of soma movement was $11.5 \mu \mathrm{m} / \mathrm{hr}$ before rounding and $3.8 \mu \mathrm{m} / \mathrm{hr}$ after rounding (Fig. $3 B$ ). One can argue that the rounding up of the soma and slowing of movement could be caused by physiological deterioration after a prolonged period of observation. However, we consider this unlikely because the cells appeared healthy, and $1.5 \mathrm{hr}$ after the soma became round, they resumed a spindle shape as they entered the deep strata of the PCL (at $180 \mathrm{~min}$ in Fig. $3 A$ ). These results demonstrate that, at the final stage of Bergmann glia- 


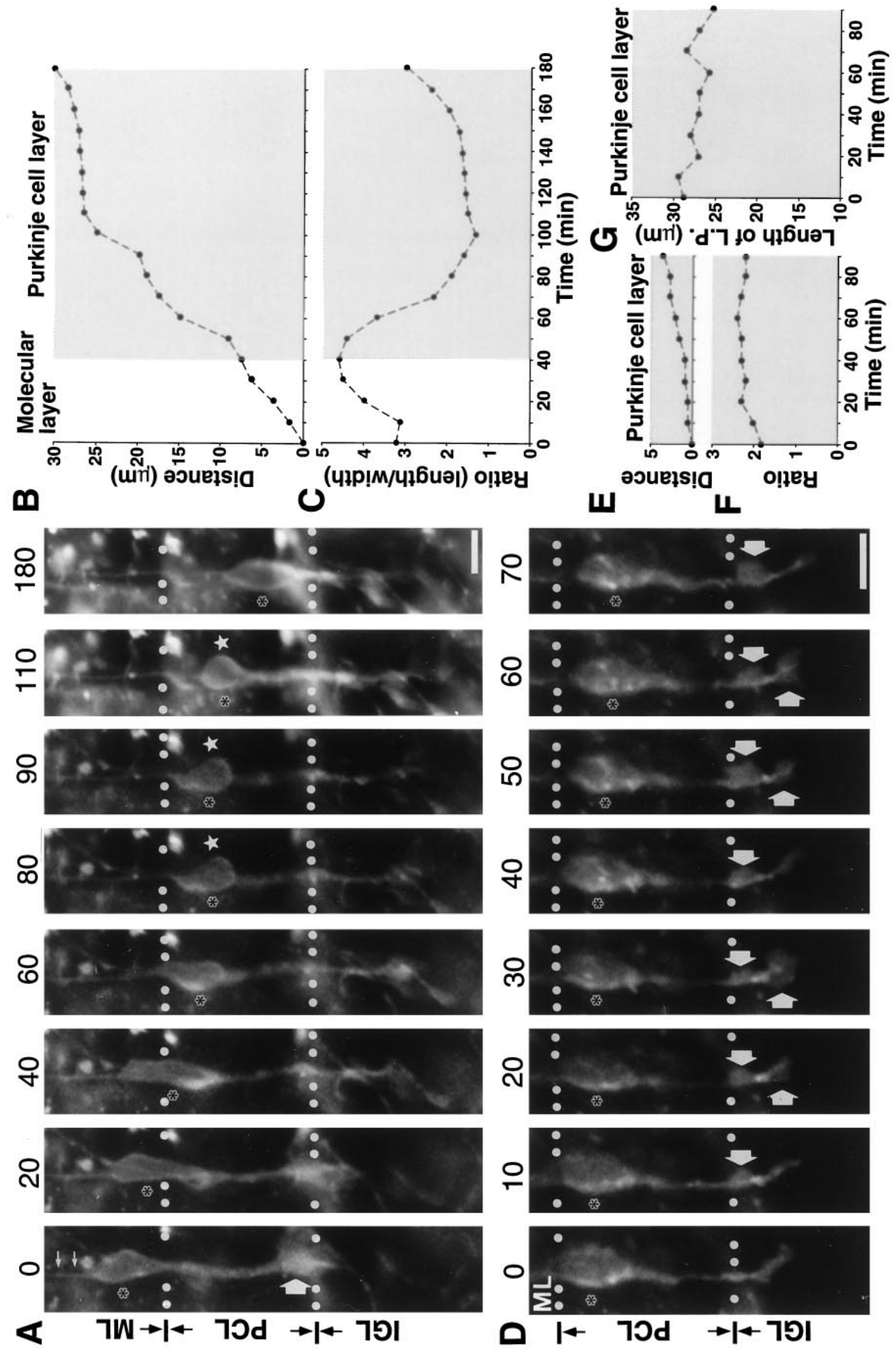


guided granule cell migration in the PCL, the granule cell abruptly changes its shape and migratory behavior.

To determine whether granule cells complete their migration after losing their contact with Bergmann glial cells in the PCL, we examined the subsequent behavior of rounded granule cells. Figure 3, $D$ and $E$, shows that the rounded soma of a granule cell, initially located at the upper strata of the PCL, remained stationary and did not change its shape throughout the observation period. The length/width ratio during this period was consistently low, with a range of 1.9-2.2 (Fig. 3F). However, highly motile lamellipodia (Fig. 3D, wide arrows) develop at the distal portion of the leading process that penetrates the IGL, although the leading process does not exhibit a net extension in length (Fig. $3 G$ ). These results demonstrate that, after losing attachment to glial surfaces, rounded granule cells remain stationary for an extensive period. However, the tips of their leading processes exhibit alternative changes that range from a tapered to a more broad form, suggesting that the leading process tips of roundshaped granule cells actively search for potential guidance cues.

\section{Renewal of granule cell migration in the IGL}

We analyzed a total of 36 rounded granule cells in the PCL and found that they remained stationary for an average of $115 \pm 18$ min, with times ranging from 30 to $220 \mathrm{~min}$. Moreover, rounded granule cells in the PCL did not exhibit any signs of further differentiation into their mature form, such as extending several thin processes from the soma. After this stationary period, however, the granule cell began to re-extend its soma and leading process (Fig. 4A). During its transformation in cell body shape (length/width ratio of 2.1-2.3 to 3.7-4.2) and the extension of the leading process $(19-30 \mu \mathrm{m})$, the granule cell gradually accelerated the rate of its migration from 2.8 to $7.7 \mu \mathrm{m} / \mathrm{hr}$ (Fig. $4 B-D$ ). Finally, $130 \mathrm{~min}$ after the start of recording, the spindle-shaped soma had crossed the PCL-IGL borderline (Fig. 4A). Thus, granule cells do not complete their migration in the PCL as commonly assumed but, rather, initiate a new phase of their migration within the IGL, which is independent of Bergmann glial fibers.

To determine whether granule cells could exhibit active and directed migration in the IGL in the absence of glial guidance, we examined the migratory behavior of granule cells in the IGL. Figure 5, $A$ and $B$, shows that a spindle-shaped granule cell soma, initially located in the upper strata of the IGL $(20 \mu \mathrm{m}$ away from the PCL-IGL border), migrated toward the deep strata of the IGL at a rate of $12.3 \mu \mathrm{m} / \mathrm{hr}$. The long axis of its soma remained oriented perpendicular to the PCL-IGL boundary line during this radial migration, and its soma shape remained a vertically elongated spindle (length/width ratio of 3.9-5.3; Fig. 5C). Surprisingly, the size, shape, and rate of movement of this soma are comparable to those recorded for granule cells migrating within the ML (Komuro and Rakic, 1995; compare with Figs. 1C, 5C).

The direction of cell body movement among 33 granule cells examined in the IGL was within an angle of $30^{\circ}$ to a perpendicular line drawn between the PCL-IGL and IGL-white matter (WM) boundaries. These observations reveal that granule cells migrate rapidly, radially, and unidirectionally toward the deep strata of the IGL in the absence of guidance cues provided by Bergmann glial cells. Therefore, these results suggest that other sets of localized guidance cues and different cellular and molecular mechanisms may regulate the shape and movement of granule cells within the IGL.

\section{Cessation of granule cell movement in the deep strata of the IGL}

After granule cells reach their final destination, they form dendrites and establish synapses with waiting mossy fibers and Golgi cell axon terminals (Rakic, 1971). However, it is not known whether granule cells stop migrating at a specific position within the IGL. To resolve this issue, we examined in slice preparations where and how granule cells complete their migration in the IGL. Figure $6 A$ shows that a granule cell soma, initially located in the middle of the IGL ( $78 \mu \mathrm{m}$ away from the PCL-IGL border and 62 $\mu \mathrm{m}$ away from the IGL-WM border), migrated radially toward the IGL-W M border at a rate of $14.7 \mu \mathrm{m} / \mathrm{hr}$ (Fig. 6B). However, after $70 \mathrm{~min}$ of recording, the active tip of the leading process approached the IGL-WM border, and the cell soma became rounded, with a change of its length/width ratio from a range of $3.0-3.8$ to $1.4-1.6$ (Fig. $6 C$ ). Furthermore, the granule cell gradually slowed its migration and after 100 min of recording completely stopped its movement $27 \mu \mathrm{m}$ away from the IGL-WM border (Fig. 6A,B). Although the soma of the granule cell ceased movement in the deep strata of the IGL, its leading process exhibited dynamic changes in shape. For example, the tip of the leading process turned to the left (Fig. 6A, open arrow at $110 \mathrm{~min}$ ) and then retracted (Fig. 6D).

In the postnatal 10 -d-old mouse cerebellum, the IGL in the pyramis, close to the midline, is $\sim 150 \mu \mathrm{m}$ wide. To categorize the final positions of the granule cells within the IGL, we divided the width of the IGL into three strata: the top stratum, within $50 \mu \mathrm{m}$ of the PCL-IGL border; the middle stratum, within $100 \mu \mathrm{m}$ of the PCL-IGL border; and the bottom stratum, $>100 \mu \mathrm{m}$ from the PCL-IGL border. Among 33 granule cells examined, 27 cells $(82 \%)$ settled at the bottom stratum of the IGL, 4 cells $(12 \%)$ settled at the middle stratum, and 2 cells $(6 \%)$ settled at the top stratum. The average distance between the PCL-IGL border and the final position of granule cells in the IGL was $113 \pm 5 \mu \mathrm{m}(n=$ 33). These results reveal that, after entering the IGL, most granule cells migrate radially $>100 \mu \mathrm{m}$, independent of glial fibers toward the IGL-WM border, suggesting that, as in the cerebral cortex, late-generated granule cells pass through the strata of early generated granule cells. Thus, a majority of granule cells complete their migration at the bottom stratum of the IGL, whereas $<20 \%$ of the granule cells settle at the middle or top strata. This suggests that granule cells may stop their movement in response to putative cues at the deep strata of the IGL; at

\footnotetext{
Figure 3. Time-lapse series showing an example of transformation and translocation of a granule cell in the PCL. $A$, Example of the granule cell soma (asterisks) as it transformed from a vertically elongated spindle to a spherical shape (white stars). The distal portion of its leading process developed a motile lamellipodia (wide arrow). The distance traversed by the granule cell soma $(B)$ and the length/width ratio of the soma $(C)$ were plotted as a function of elapsed time. $D$, Time-lapse series showing a dynamic change in shape of leading process of stationary granule cell. Although the rounded soma of the granule cell remained stationary throughout the observation period, highly motile lamellipodia (wide arrows) were present at a distal portion of the leading process. The distance traversed by the granule cell soma $(E)$, the length/width ratio of the soma $(F)$, and the leading process length $(G)$ were plotted as a function of elapsed time. $I G L$, Internal granular layer; $P C L$, Purkinje cell layer; $M L$, molecular layer. Scale bar, $10 \mu \mathrm{m}$. Time interval (in minutes) is indicated on the top.
} 

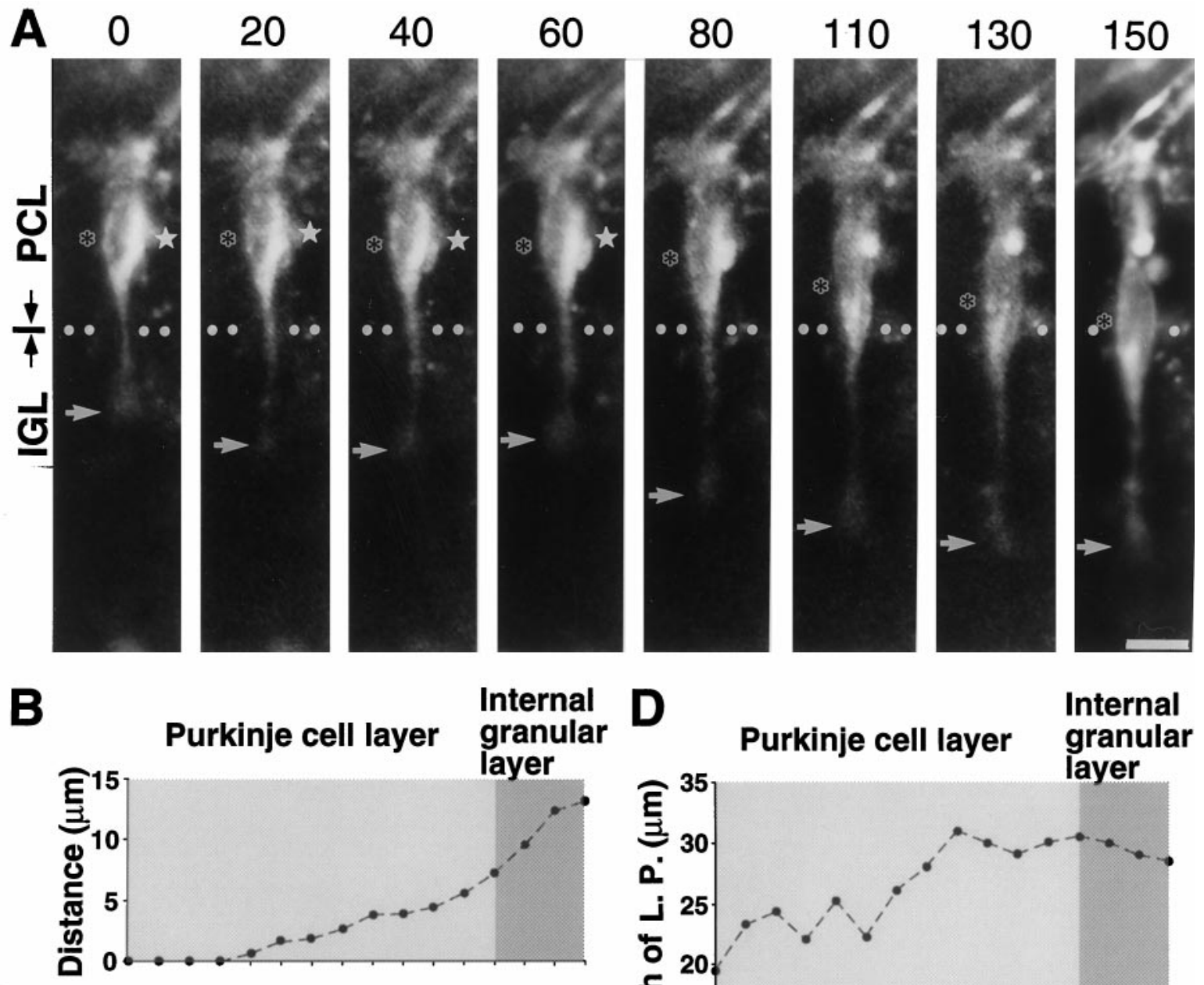

C
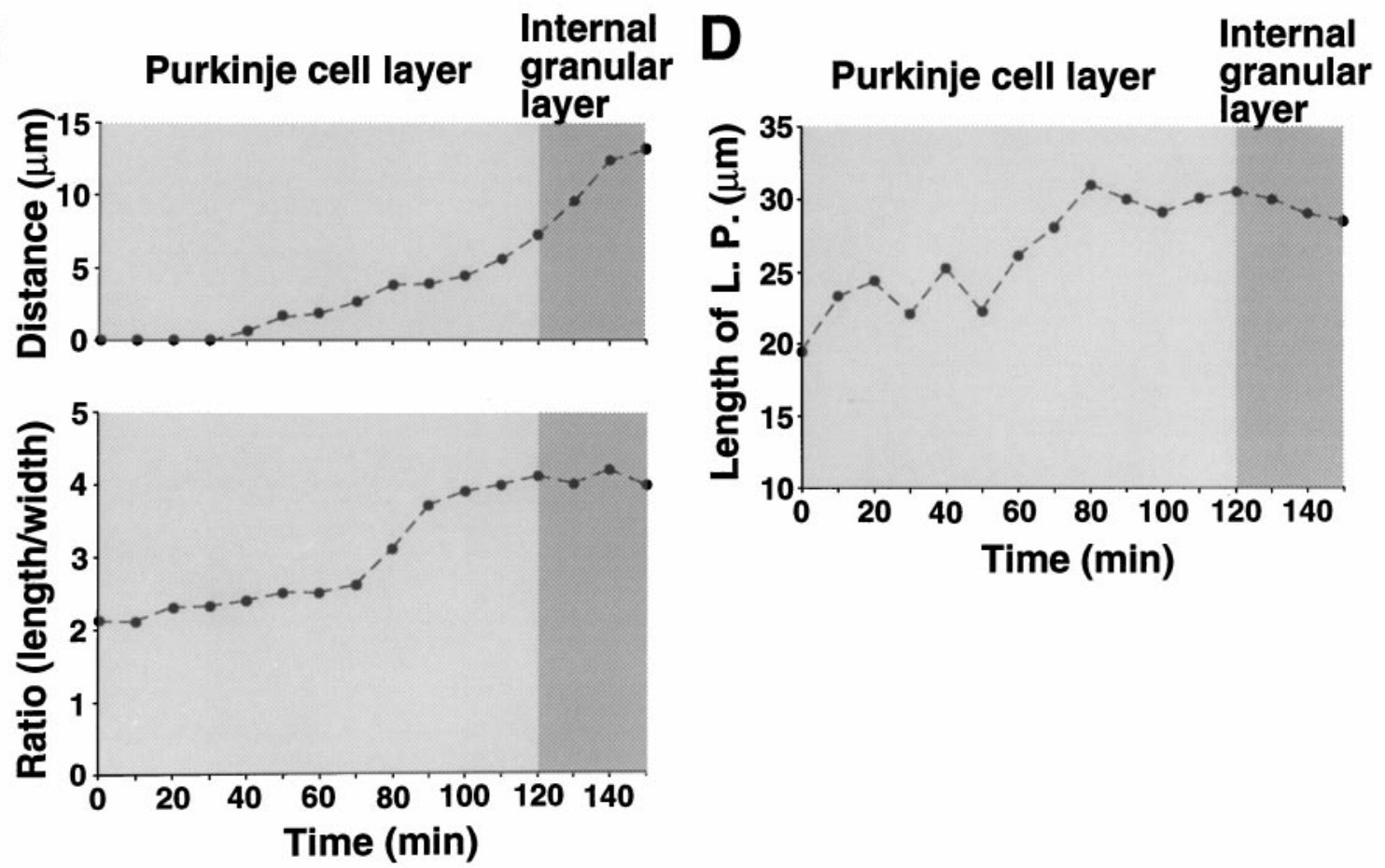

Figure 4. Time-lapse series showing an example of secondary transformation of a rounded granule cell at the PCL-IGL border. $A$, During the observation period, a rounded granule cell (white asterisks) began to re-extended its soma and leading process. Arrows indicate a broad tip of a leading process. The distance traversed by the granule cell soma $(B)$, the length/width ratio of the soma $(C)$, and the leading process length $(D)$ were plotted as a function of elapsed time. $I G L$, Internal granular layer; $P C L$, Purkinje cell layer. Scale bar, $10 \mu \mathrm{m}$. Time interval (in minutes) is indicated on the top.

present, it is unknown which cells or candidate molecules identified in the deep strata of the IGL are involved in this process.

\section{Length and duration of granule cell transit across the ML, PCL, and IGL}

In the postnatal 10-d-old mouse cerebellum, postmitotic granule cells migrate radially $\sim 250 \mu \mathrm{m}$ to attain their final position in the IGL. Of this total length, the cells move $\sim 110 \mu \mathrm{m}$ to cross the
ML, $\sim 27 \mu \mathrm{m}$ to traverse the PCL, and an additional $113 \mu \mathrm{m}$ in the IGL toward the IGL-WM border. This indicates that the distance traversed by granule cells in the IGL is similar to that traversed by the granule cells along Bergmann glial fibers in the ML (Komuro and Rakic, 1995).

To determine the transit time of granule cells in the ML and PCL and the time required by granule cells to attain their final position in the IGL, the width of the ML and PCL and the 

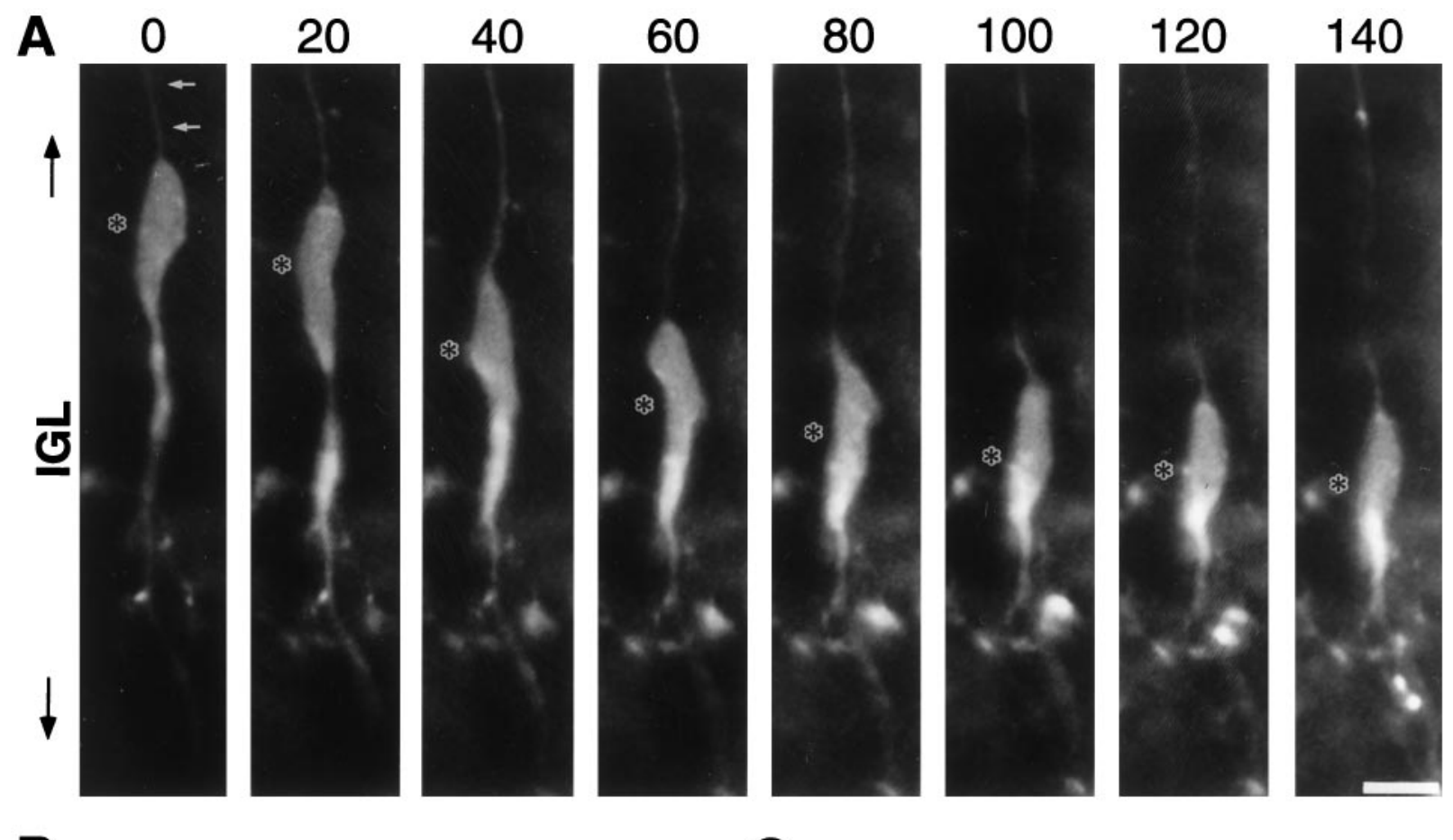

B
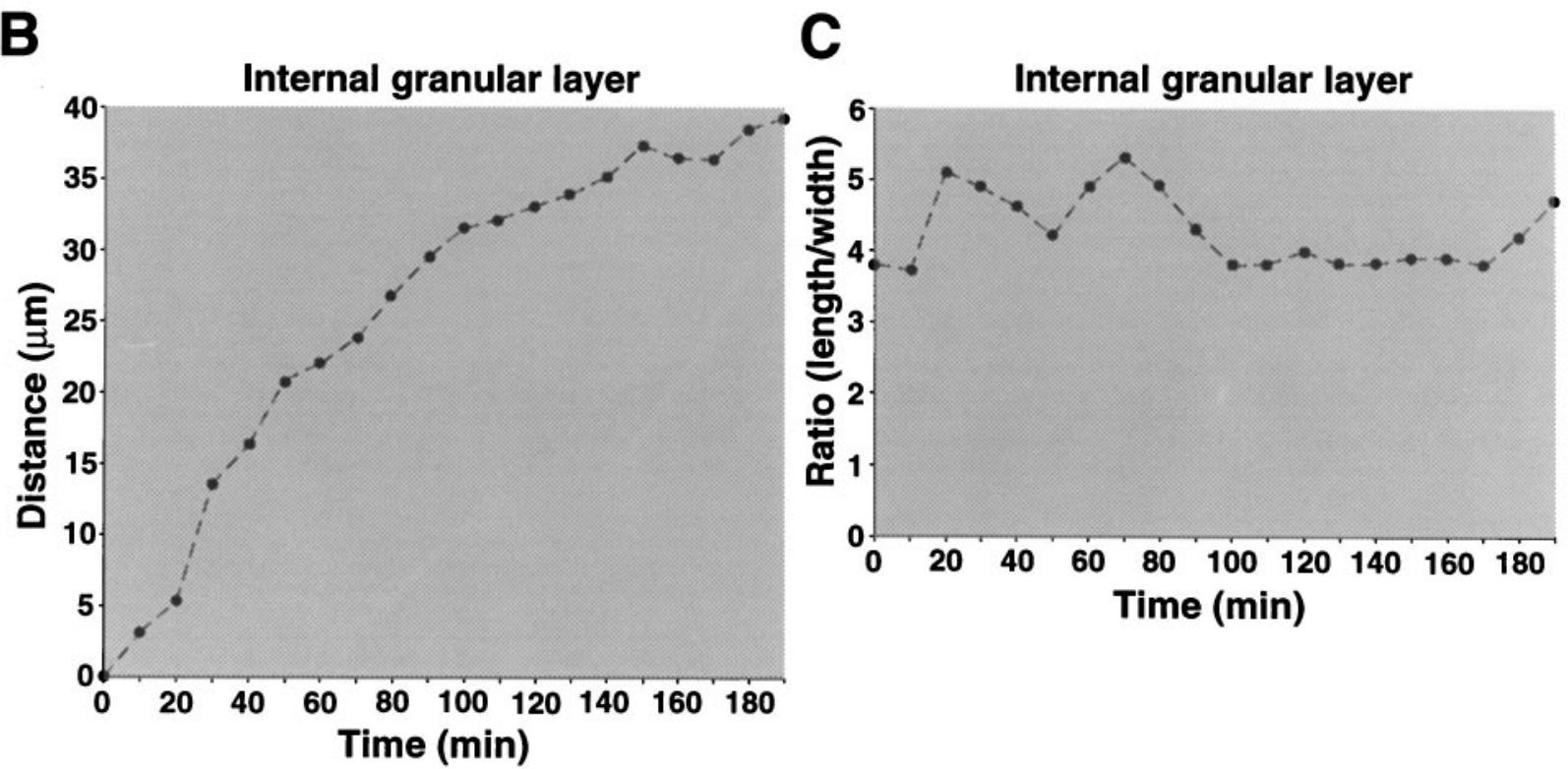

Figure 5. Time-lapse series showing an example of migration of a granule cell at the upper strata of the IGL. $A$, During the observation period, the spindle-shaped soma (asterisks) of a granule cell translocated vertically toward the deep strata of the IGL at a rate of $12.3 \mu \mathrm{m} / \mathrm{hr}$. Small arrows indicate the trailing process of the migrating granule cell. The distance traversed by the granule cell soma $(B)$ and the length/width ratio of the soma $(C)$ were plotted as a function of elapsed time. IGL, Internal granular layer. Scale bar, $10 \mu \mathrm{m}$. Time interval (in minutes) is indicated on the top.

translocated distance in the IGL were divided by the average rate of cell movement at each layer. The average rate of granule cell movement was $11.2 \pm 0.9 \mu \mathrm{m} / \mathrm{hr}(n=38)$ in the ML, $5.2 \pm 0.8$ $\mu \mathrm{m} / \mathrm{hr}(n=36)$ in the PCL, and $10.2 \pm 1.1 \mu \mathrm{m} / \mathrm{hr}(n=33)$ in the IGL (Fig. 7D). Therefore, the average transit time was $9.8 \mathrm{hr}$ in the ML and 5.2 hr in the PCL, and the time required to attain their final position in the IGL was $11.1 \mathrm{hr}$. These results suggest that granule cells move from the premigratory zone of the EGL through the ML and the PCL to their final position in the IGL within $1 \mathrm{~d}$ (average, $26 \mathrm{hr}$ ) after the initiation of radial migration.

Despite the decreased rate of cell movement in the PCL, no accumulation of granule cells has been observed, because equal numbers of cells arrive and leave this layer at any given time. Our previous study indicates that granule cells migrating along a Bergmann glial fiber arrive in the PCL within 5-10 hr (Komuro and Rakic, 1995). They remain in the PCL for $\sim 5 \mathrm{hr}$ before entering the IGL. Therefore, the number of granule cells in the PCL is stable throughout the entire development period.

In summary, the total length of the migratory pathway of granule cells in the developing mouse cerebellum is $\sim 250 \mu \mathrm{m}$, but during this short journey they pass through three distinct cellular compartments (ML, PCL, and IGL). As presented quantitatively in the histograms (Fig. $7 A-D$ ), there is a direct and consistent relationship between cell shape (expressed as the ratio 

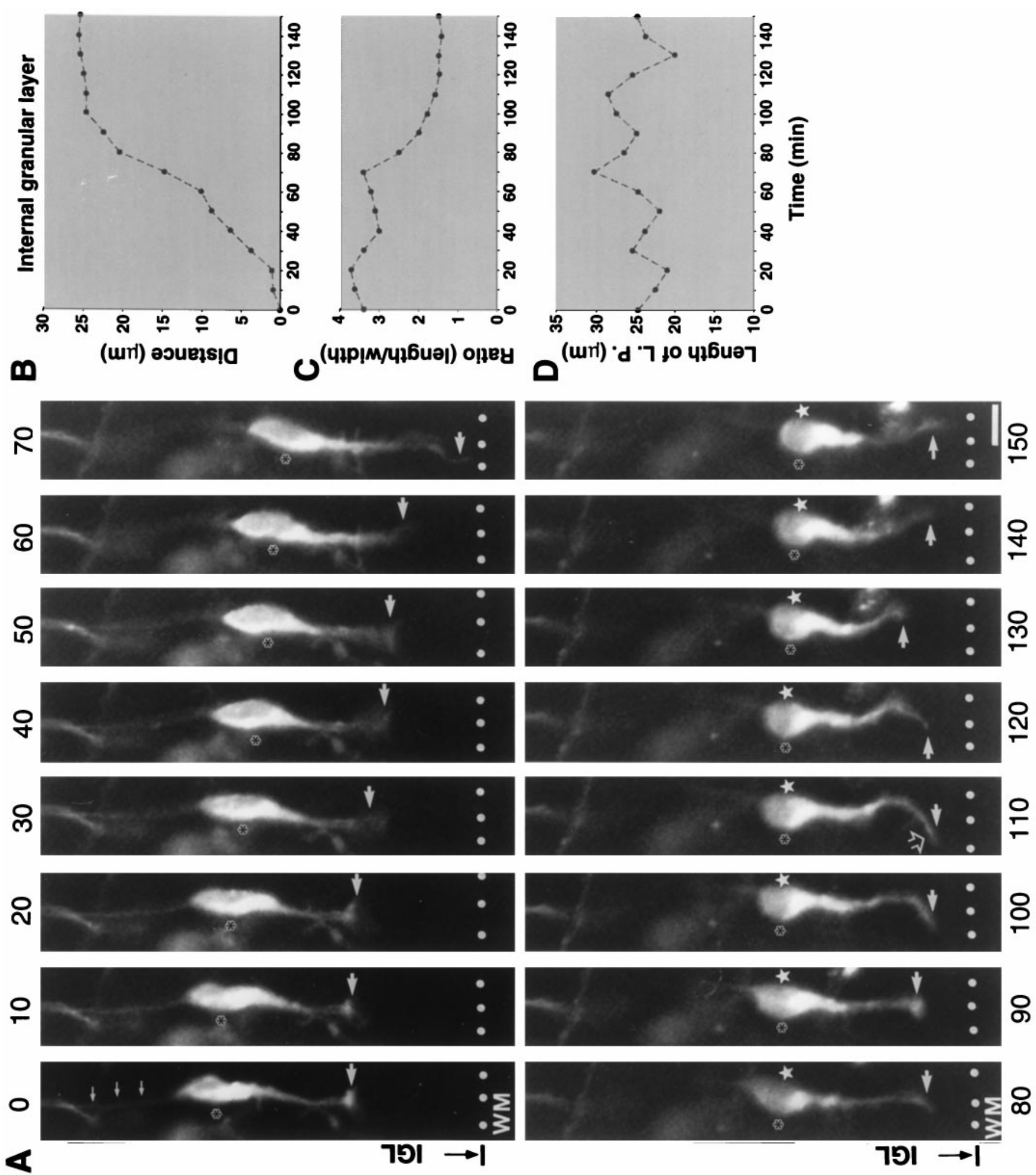

Figure 6. Time-lapse series showing an example of vertical migration of a granule cell at the middle strata of the IGL. $A$, During the observation period, the spindle-shaped soma (asterisk) migrated vertically toward the IGL-WM border. White arrows and white stars indicate the tip of a leading process and the rounded soma of the migrating cell, respectively. An open arrow indicates the horizontally extended tip of its leading process, whereas small arrows indicate the trailing process of the migrating granule cell. The distance traversed by the granule cell soma $(B)$ and the length/width ratio of the soma (C) were plotted as a function of elapsed time. $I G L$, Internal granular layer; $W M$, white matter. Scale bar, $10 \mu \mathrm{m}$. Time interval (in minutes) is indicated on either the top or bottom. 


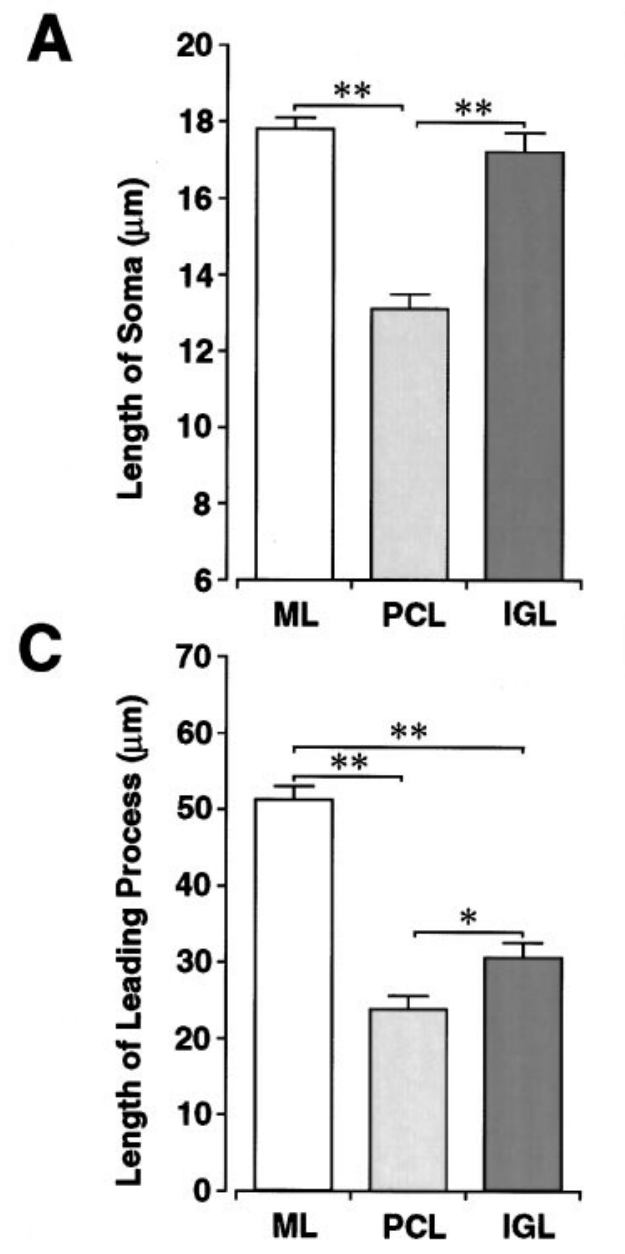

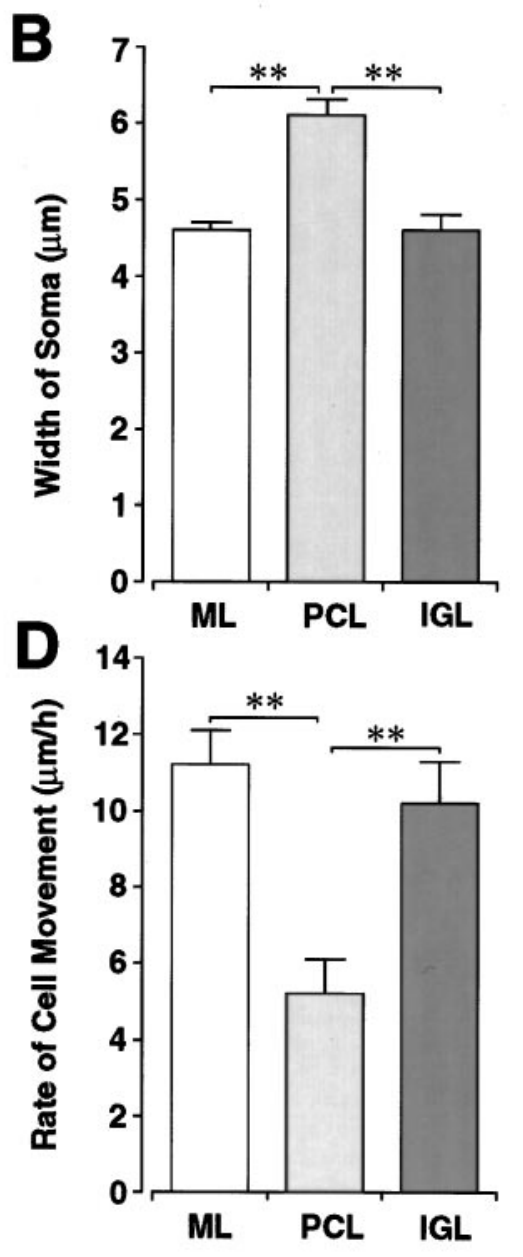

Figure 7. Relationship between morphology and rate of movement of granule cell through different layers of developing cerebellar cortex. $A-D$, Histograms of soma length $(A)$, soma width $(B)$, leading process length $(C)$, and movement rate of granule cells $(D)$ in the ML, PCL, and IGL of developing cerebellum. Each column represents the average values obtained from 38 migrating granule cells in the ML, 36 cells in the PCL, and 33 cells in the IGL. Single $(p<0.05)$ and double $(p<0.01)$ asterisks indicate statistical significance. $I G L$, Internal granular layer; $P C L$, Purkinje cell layer; $M L$, molecular layer. between the width and length of cell soma), the length of the leading process, and the rate of cell movement.

\section{DISCUSSION}

It is generally agreed that the mode and rate of neuronal migration in the central and peripheral nervous systems depend on the surface-mediated interactions with the cellular environments encountered by the moving cells (Rakic, 1990; Bronner-Fraser, 1993, 1995; Anton et al., 1997). However, until recently it was not possible to observe migrating cells directly in their natural setting as they move across the different migratory terrains. Use of the real-time recording of cell movement in cerebellar slice preparations (Komuro and Rakic, 1995) enables analysis of changes in granule cell shape, mode, and tempo of their migration during their transit across the ML, PCL, and IGL. The basic changes observed in the present study can be subdivided into several stages as summarized in Figure 8: (1) in the ML granule cells have a distinct bipolar soma with long leading processes as they migrate toward the PCL along Bergmann glial fibers; (2) after the tips of the leading processes penetrate the PCL they abruptly stop growing, whereas granule cell nuclei continue to move toward the PCL; (3) after entering the PCL, granule cell somata become rounded, and their movement transiently stops; (4) within the PCL, the granule cell somata remain stationary for $\sim 2$ hr while their leading processes develop new motile lamellipodia; (5) at the PCL-IGL border, granule cells again assume a spindle shape and resume migration; (6) at the top and middle strata of the IGL, some granule cells acquire a round shape and stop movement, but the majority of cells remain spindle-shaped and continue to move radially toward the bottom of the IGL; and (7) at the bottom strata of the IGL these cells again become rounded, and their locomotion finally stops.

These observations stand in contrast to early studies using $\left[{ }^{3} \mathrm{H}\right]$ thymidine autoradiography, which have suggested that isochronically generated granule cells stop their migration randomly throughout the IGL (Miale and Sidman, 1961; Fujita et al., 1966; Altman, 1972). However, the present results indicate that the majority of granule cells migrating at postnatal day 10 eventually settle in the deep strata of the IGL, without respect to the time of their origin. It is well established that some cells continue to proliferate within the IGL, although the final positions and eventual phenotypes of these cells remain unclear (Uzman, 1960; Fujita et al., 1966). Because the IGL contains other neuronal classes in addition to granule cells (Altman and Bayer, 1977; Mugnaini and Floris, 1994), the estimation of final positions of granule cells in the IGL using $\left[{ }^{3} \mathrm{H}\right]$ thymidine autoradiography includes a mixed population of cells. This could explain the apparent discrepancy between $\left[{ }^{3} \mathrm{H}\right]$ thymidine observation and our results.

Previous in vitro studies demonstrated that both the cytology and migratory behavior of granule cells are highly responsive to the substrates to which they become attached (Fishell and Hatten, 1991; Fishman and Hatten, 1993; Rivas and Hatten, 1995). For 
Figure 8. Schematic representation of the morphogenetic transformation of granule cells as they migrate across various cellular compartments of the developing cerebellar cortex. $E G L$, External granular layer; $M L$, molecular layer; $P C L$, Purkinje cell layer; $I G L$, internal granular layer; $W M$, white matter; $B G$, Bergmann glial cell; $G$, postmigratory granule cell; $P C$, Purkinje cell.

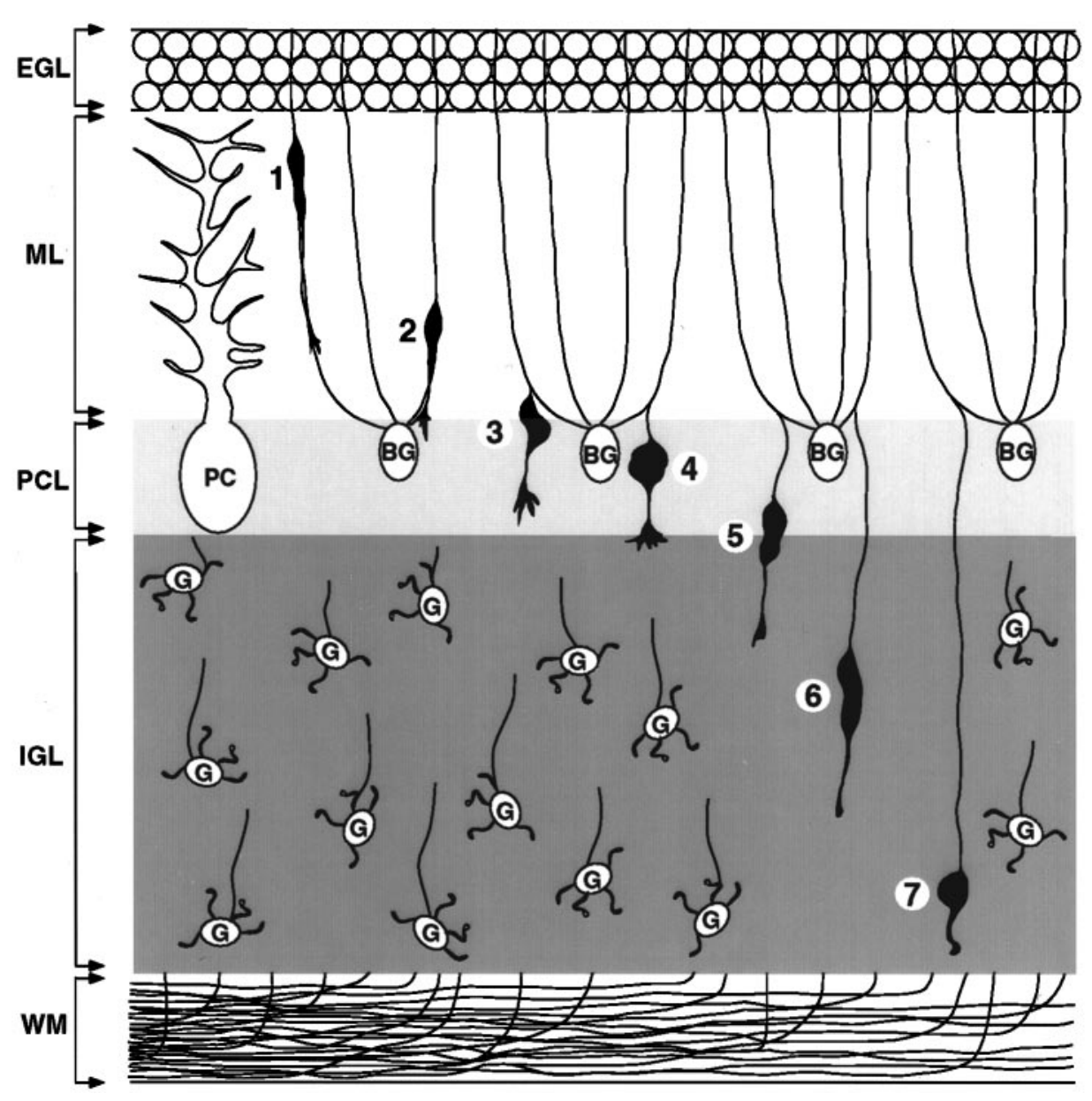

example, dissociated granule cells display an elongated bipolar migrating shape when they are plated onto either astroglial plasma membranes, laminin, or fibronectin, whereas cells are rounded when plated on collagen (Fishell and Hatten, 1991). Although in vivo studies showed that granule cells traverse three distinct cellular compartments (ML, PCL, and IGL), thus far only the candidate molecules involved in the phase of migration through the ML have been studied (Hatten and Mason, 1990; Cameron and Rakic, 1994; Rakic et al., 1994; Hatten and Heintz, 1995; Anton et al., 1996; Rio et al., 1997). It is possible that migrating granule cells are guided by various extracellular matrix molecules that are expressed in distinct distributions in the PCL and the IGL (Chuong, 1990). Dissociated granule cells migrate well on extracellular matrix molecules in the absence of either glial or axonal processes (Liesi, 1992; Fishman and Hatten, 1993). Alternatively, later-generated granule cells could migrate along the ascending axons of earlier-generated granule cells that are already present in the IGL. While migrating across the ML, granule cells are apposed to both the Bergmann glial fibers and the fascicles of the ascending axons of earlier-generated granule cells (shown in Rakic, 1971, his Fig. 15B). In microexplant cultures, granule cells move along the neurites of differentiating granule cells (Nagata and Nakatsuji, 1990; Komuro and Rakic, 1996). Interestingly, in the developing cerebrum, a specific population of migrating neurons changes its affiliation with radial glial processes to axonal fascicles (O'Rourke et al., 1992). Therefore, vertically oriented axons of postmigratory granule cells might also support the inward migration of later-generated gran- ule cells as they transit the PCL and the IGL. However, we cannot exclude the possibility that glial cells continue to play a role in granule cell migration, particularly within the upper strata of the IGL. Bergmann glial cells extend short vertical processes into the upper strata of the IGL during the period of granule cell migration (shown in Rakic, 1971, his Fig. 6; Muller et al., 1994). After granule cell migration is completed, Bergmann glial cells withdraw short vertical processes (Rakic, 1971; Muller et al., 1994), suggesting that granule cells that settle in the upper strata of the IGL may migrate along these glial processes in the same way that they do in the ML. However, because the tips of the short glial processes do not fully span the IGL, granule cells that settle in its deep strata require another substrate to reach their final position.

The migration of granule cells in the IGL might be regulated by cues from mossy fibers, axons of Golgi type II cells that eventually form synapses with postmigratory granule cells, or both; both are present in the IGL before the arrival of granule cells (Rakic and Sidman, 1973; Mason and Gregory, 1984). Most mossy fiber terminals accumulate at the interface of the PCL and IGL where they "wait" for incoming granule cells (Rakic and Sidman, 1970). It has been suggested that granule cells may be attracted by molecules released from mossy fiber terminals and "pick up" their connections after arriving at the PCL-IGL interface (Rakic and Sidman, 1970; Rakic, 1985). Indeed, deprivation of mossy fiber input originating from the pons results in the curtailment of granule cell migration (Hamori, 1969). Furthermore, terminals of mossy fibers release glutamate, which could change intracellular $\mathrm{Ca}^{2+}$ levels in granule cells by modifying $\mathrm{Ca}^{2+}$ influx across their 
plasma membrane (Bisti et al., 1971; Connor et al., 1987; Garthwaite and Brodbelt, 1989, 1990; Rossi and Slater, 1993). In the microexplant culture, migrating granule cells exhibit spontaneous fluctuations of intracellular $\mathrm{Ca}^{2+}$ levels, and depression of the amplitude and frequency components of $\mathrm{Ca}^{2+}$ fluctuations by blockade of $\mathrm{Ca}^{2+}$ influx across the plasma membrane results in a reversible retardation of cell movement (Komuro and Rakic, 1996). Selective blockade of the activity of the NMDA subtype of glutamate receptor decreases the rate of granule cell movement in acute slices (Komuro and Rakic, 1993), whereas overactivation of NMDA receptors results in the arrest of neuronal migration in vivo (Marret et al., 1996). Another possible source of attraction for migrating granule cells is Golgi type II cell terminals, which release GABA. Application of GABA modifies the migrating behavior of cortical neurons in a dose-dependent manner by changing intracellular calcium levels (Behar et al., 1996). Thus, the neurotransmitters released from prospective presynaptic fibers, such as mossy fibers and Golgi cell axons, could regulate the rate, as well as duration, of granule cell migration by modifying the intracellular $\mathrm{Ca}^{2+}$ levels. Furthermore, age-related changes in the concentration of glutamate and GABA in the extracellular space of the IGL may affect the migratory behavior of granule cells generated at different times.

Another possibility is that changes in granule cell shape and mode of their migration in different cellular compartments of the cerebellar cortex might be induced by intrinsic signals. Diversification of postmitotic cells into multiple cell phenotypes minutes after final mitotic division, and before arrival at the target destination, has been demonstrated in a variety of developing structures (Trisler et al., 1996; Meissirel et al., 1997). In particular, cells destined for the various layers of the cerebral cortex seem to be specified in the proliferative ventricular zone (McConnell and Kaznowski, 1991). Thus, it is possible that the postmitotic granule cells are specified to settle in different strata of the IGL. It has been shown that migrating cerebellar granule cells express several genes at specific points along their pathway, and some of these genes encode for specific receptors activated by cell adhesion molecules (Kuhar et al., 1993; Rocamora et al., 1993; Friedman and Seeds, 1995; Hatten and Heintz, 1995; Zheng et al., 1996; Hatten et al., 1997). Although the role of these genes in the developing cerebellum has not been determined, it has been shown that mutated cell adhesion molecule-related kinase genes can transform fibroblasts from a typical polar migratory shape to a more rounded shape and can dramatically reduce mobility compared with the wild type (Ilic et al., 1995). Furthermore, laminar and cytoarchitectonic abnormalities of cerebral and cerebellar cortices may be caused by mutation of specific genes that are involved in the completion of migration (Howell et al., 1997; Sheldon et al., 1997; Ware et al., 1997). Therefore, alternating gene expression during the translocation of migrating granule cells from the EGL to the IGL may function to modulate changes in their shape and behavior, as well as their allocation. The use of slice preparations in conjunction with confocal microscopy allows for the examination of the role of various molecules and the uncovering of mechanisms underlying cell migration through the heterogeneous terrain of the developing mammalian brain.

\section{REFERENCES}

Altman J (1972) Postnatal development of the cerebellar cortex in the rat. III. Maturation of the components of the granular layer. J Comp Neurol 145:465-514.

Altman J, Bayer SA (1977) Time of origin and distribution of a new cell type in the rat cerebellar cortex. Exp Brain Res 29:265-274.
Anton E, Cameron RS, Rakic P (1996) Role of neuron-glial junctional domain proteins in the maintenance and termination of neuronal migration across the embryonic cerebral wall. J Neurosci 16:2283-2293.

Anton E, Marchionni MA, Lee K-F, Rakic P (1997) Role of GGF/ neuregulin signaling in interactions between migrating neurons and radial glia in the developing cerebral cortex. Development 124:3501-3510.

Behar TN, Li Y-X, Tran HT, Ma W, Dunlap V, Scott C, Baker JL (1996) GABA stimulates chemotaxis and chemokinesis of embryonic cortical neurons via calcium-dependent mechanisms. J Neurosci 16:1808-1818.

Bisti S, Iosif G, Marchesi GF, Strata P (1971) Pharmacological properties of inhibitions in the cerebellar cortex. Exp Brain Res 14:24-37.

Bronner-Fraser M (1993) Environmental influences on neural crest cell migration. J Neurobiol 24:233-247.

Bronner-Fraser M (1995) Patterning of the vertebrate neural crest. Perspect Dev Neurobiol 3:53-62.

Cameron RS, Rakic P (1994) Identification of membrane proteins that comprise the plasmalemmal junction between migrating neurons and radial glial cells. J Neurosci 14:3139-3155.

Cameron RS, Ruffin J, Cho NK, Cameron PL, Rakic P (1997) Developmental expression, pattern of distribution, and effect on cell aggregation implicate a neuron-glial junctional domain protein in neuronal migration. J Comp Neurol 387:467-488.

Choung C-M (1990) Differential roles of multiple adhesion molecules in cell migration: granule cell migration in cerebellum. Experientia 46:892-899.

Choung C-M, Crossin KL, Edelman GM (1987) Sequential expression and differential function of multiple adhesion molecules during the formation of cerebellar cortical layers. J Cell Biol 104:331-342.

Connor JA, Tseng H-Y, Hockberger PE (1987) Depolarization- and transmitter-induced changes in intracellular $\mathrm{Ca}^{2+}$ of rat cerebellar granule cells in explant cultures. J Neurosci 7:1384-1400.

Edmondson JC, Hatten ME (1987) Glial-guided granule neuron migration in vitro: a high-resolution time-lapse video microscopic study. J Neurosci 7:1928-1934.

Fishell G, Hatten ME (1991) Astrotactin provides a receptor system for CNS neuronal migration. Development 113:755-765.

Fishman RB, Hatten ME (1993) Multiple receptor systems promote CNS neuronal migration. J Neurosci 13:3485-3495.

Friedman GC, Seeds NW (1995) Tissue plasminogen activator mRNA expression in granule neurons coincides with their migration in the developing cerebellum. J Comp Neurol 360:658-670.

Fujita S (1967) Quantitative analysis of cell proliferation and differentiation in the cortex of the postnatal mouse cerebellum. J Cell Biol 32:277-287.

Fujita S, Shimada M, Nakamura T (1966) ${ }^{3}$ H-Thymidine autoradiographic studies on the cell proliferation and differentiation in the external and the internal granular layers of the mouse cerebellum. J Comp Neurol 128:191-208.

Garthwaite J, Brodbelt AR (1989) Synaptic activation of $N$-methyl-Daspartate and non- $N$-methyl-D-aspartate receptors in the mossy fiber pathway in adult and immature rat cerebellar slices. Neuroscience 29:401-412.

Garthwaite J, Brodbelt AR (1990) Glutamate as the principal mossy fiber transmitter in rat cerebellum: pharmacological evidence. Eur J Neurosci 2:177-180.

Hamori J (1969) Development of synaptic organization in the partially agranular and in transneuronally atrophied cerebellar cortex. In: Neurobiology of cerebellar evolution and development (Llinas R, ed), pp 845-858. Chicago: American Medical Association.

Hatten ME, Heintz N (1995) Mechanisms of neural patterning and specification in the developing cerebellum. Annu Rev Neurosci 18:385-408.

Hatten ME, Mason CA (1990) Mechanisms of glial-guided neuronal migration in vitro and in vivo. Experientia 46:907-916.

Hatten ME, Alder J, Zimmerman K, Heintz N (1997) Genes involved in cerebellar cell specification and differentiation. Curr Opin Neurobiol 7:40-47.

Honig ME, Hume CA (1986) Fluorescent carbocyanine dyes allow living neurons of identified origin to be studied in long-term cultures. J Cell Biol 103:171-187.

Howell BW, Hawkes R, Soriano P, Cooper JA (1997) Neuronal position in the developing brain is regulated by mouse disabled-1. Nature 389: 733-737. 
Ilic D, Furuta Y, Kanazawa S, Takeda N, Sobue K, Nakatsuji N, Nomura S, Fujimoto J, Okada M, Yamamoto T, Aizawa S (1995) Reduced cell motility and enhanced focal adhesion contact formation in cells from FAK-deficient mice. Nature 377:539-544.

Komuro H, Rakic P (1992) Selective role of N-type calcium channels in neuronal migration. Science 257:806-809.

Komuro H, Rakic P (1993) Modulation of neuronal migration by NMDA receptors. Science 260:95-97.

Komuro H, Rakic P (1995) Dynamics of granule cell migration: a confocal microscopic study in acute cerebellar slice preparations. J Neurosci 15:1110-1120.

Komuro H, Rakic P (1996) Intracellular $\mathrm{Ca}^{2+}$ fluctuations modulate the rate of neuronal migration. Neuron 17:275-285.

Komuro H, Rakic P (1997) In vitro analysis of signal mechanisms involved in neuronal migration. In: The neuron in tissue culture (Haynes LW, ed), New York: Wiley, in press.

Kuhar SG, Feng L, Vidan S, Ross ME, Hatten ME, Heintz N (1993) Changing patterns of gene expression define four stages of cerebellar granule neuron differentiation. Development 117:97-104.

Liesi P (1992) Neuronal migration on laminin involves neuronal contact formation followed by nuclear movement inside a preformed process. Exp Neurol 117:103-113.

Marret S, Gressens P, Evrard P (1996) Arrest of neuronal migration by excitatory amino acids in hamster developing brain. Proc Natl Acad Sci USA 93:15463-15468.

Mason CA, Gregory E (1984) Postnatal maturation of cerebellar mossy and climbing fibers: transient expression of dual features on single axons. J Neurosci 7:1715-1735.

McConnell SK, Kaznowski CE (1991) Cell cycle dependence of laminar determination in developing neocortex. Science 254:282-285.

Meissirel C, Wikler KC, Chalupa LM, Rakic P (1997) Early divergence of magnocellular and parvocellular functional subsystems in the embryonic primate visual system. Proc Natl Acad Sci USA 94:5900-5905.

Miale IL, Sidman RL (1961) An autoradiographic analysis of histogenesis in the mouse cerebellum. Exp Neurol 4:277-296.

Mugnaini E, Floris A (1994) The unipolar brush cell: a neglected neuron of the mammalian cerebellar cortex. J Comp Neurol 339:174-180.

Mugnaini E, Forstronen PF (1967) Ultrastructual studies on the cerebellar histogenesis. I. Differentiation of granule cells and development of glomeruli in the chick embryo. Z Zellforsch 77:115-143.

Muller T, Fritschy JM, Grosche J, Pratt GD, Mohler H, Kettermann H (1994) Developmental regulation of voltage-gated $\mathrm{K}^{+}$channel and $\mathrm{GABA}_{\mathrm{A}}$ receptor expression in Bergmann glial cells. J Neurosci 14:2503-2514.

Nagata I, Nakatsuji N (1990) Granule cell behavior on laminin in cerebellar microexplant cultures. Dev Brain Res 52:63-73.

O'Rourke NA, Dailey ME, Smith SJ, McConnell SK (1992) Diverse migration pathways in the developing cerebral cortex. Science 258:299-302.

Rakic P (1971) Neuron-glia relationship during granule cell migration in developing cerebellar cortex. A golgi and electron microscopic study in Macacus rhesus. J Comp Neurol 141:283-312.

Rakic P (1981) Neuron-glia interaction during brain development. Trends Neurosci 4:184-187.

Rakic P (1985) Contact regulation of neuronal migration. In: The cell in contact (Edelman GE, Thiery JP, eds), pp 67-90. New York: Wiley.

Rakic P (1990) Principles of neuronal cell migration. Experientia 46:882-891.

Rakic P, Komuro H (1995) The role of receptor/channel activity in neuronal cell migration. J Neurobiol 26:299-315.

Rakic P, Sidman RL (1970) Histogenesis of cortical layers in human cerebellum, particularly the lamina dissecans. J Comp Neurol 139:473-500.

Rakic P, Sidman RL (1973) Sequence of developmental abnormalities leading to granule cell deficit in cerebellar cortex of weaver mutant mice. J Comp Neurol 152:103-132.

Rakic P, Cameron RS, Komuro H (1994) Recognition, adhesion, transmembrane signaling and cell motility in guided neuronal migration. Curr Opin Neurobiol 4:63-69.

Ramon y Cajal S (1911) Histologie du system nerveux de l'homme et des vertebres, Vol 2. Paris: Malonine.

Rio C, Rieff HI, Qi P, Corfas G (1997) Neuregulin and erbB receptors play a critical role in neuronal migration. Neuron 19:39-50.

Rivas RJ, Hatten ME (1995) Motility and cytoskeletal organization of migrating cerebellar granule neurons. J Neurosci 15:981-989.

Rocamora N, Garcia-Ladona FJ, Palacios JM, Mengod G (1993) Differential expression of brain-derived neurotrophic factor, neurotrophin-3, and low-affinity nerve growth factor receptor during the postnatal development of the rat cerebellar system. Mol Brain Res 17:1-8.

Rossi DJ, Slater NT (1993) The developmental onset of NMDA receptor channel activity during neuronal migration. Neuropharmacology 32:1239-1248.

Sheldon M, Rice DS, D'Arcangelo G, Yoneshima H, Nakajima K, Mikoshiba K, Howell BW, Cooper JA, Goldowitz D, Curran T (1997) Scrambler and yotari disrupt the disabled gene and produce a reeler-like phenotype in mice. Nature 389:730-733.

Trenkner E, Sidman RL (1977) Histogenesis of mouse cerebellum in microwell cultures. J Cell Biol 75:915-940.

Trisler D, Rutin J, Pessac B (1996) Retinal engineering: engrafted neural cell lines locate in appropriate layers. Proc Natl Acad Sci USA 93:6269-6274.

Uzman LL (1960) The histogenesis of the mouse cerebellum as studied by its tritiated thymidine uptake. J Comp Neurol 114:137-159.

Ware ML, Fox JW, Gonzalez JL, Davis NM, Lambert de Rouvroit C, Russo CJ, Chua Jr SC, Goffinet AM, Walsh CA (1997) Aberrant splicing of a mouse disabled homolog, mdab1, in the scrambler mouse. Neuron 19:239-249.

Zheng C, Heintz N, Hatten ME (1996) CNS gene encoding astrotactin, which supports neuronal migration along glial fibers. Science 272: 417-419. 